\title{
LIMITED PLASTICITY OF BIOMASS ALLOCATION IN ALPINE FORBS, PIKES PEAK, COLORADO
}

\author{
Michael M. Myerburg1,2, James J. Ebersole ${ }^{1,3}$, Lauren G. Shoemaker ${ }^{1}$, and M. Shane Heschel ${ }^{1}$
}

\begin{abstract}
Alpine plant species are thought to have limited phenotypic plasticity, but few data exist on forbs. We assessed plasticity in allocation of biomass to belowground and aboveground parts and to reproduction in 5 forb species from a 50-year-old disturbance and adjacent undisturbed areas in an alpine dry meadow. Three of the species, mostly those with variable numbers of stems per genet, increased in size in the disturbed areas. All 5 forbs showed very limited plasticity in allocation of biomass. Lack of phenotypic plasticity in these forbs may limit their ability to respond to future changes in environment.
\end{abstract}

RESUMEN.-Se cree que las especies de plantas alpinas tienen una plasticidad fenotípica limitada, pero existen pocos datos sobre la plasticidad de plantas herbáceas. Evaluamos la plasticidad en la asignación de biomasa entre las partes bajo el nivel del suelo y las partes arriba del nivel del suelo, y la plasticidad en la asignación de recursos a la reproducción para 5 especies de plantas herbáceas de una zona que fue perturbada hace 50 años y de áreas adyacentes sin perturbar en un prado seco alpino. Tres de las especies, principalmente las que tienen números variables de tallos por genet, aumentaron de talla en las áreas perturbadas. Las 5 herbáceas exhibieron plasticidad muy limitada respecto a la asignación de biomasa. La falta de plasticidad fenotípica en estas herbáceas podría limitar su capacidad para responder a cambios futuros en su entorno.

Plasticity in allocation of resources to aboveand belowground structures and to reproduction can allow plant species to persist across different environments through space and time. Knowledge of the degree of phenotypic plasticity in various environments and across growth forms allows us to understand how natural populations differentiate. This knowledge may also help us predict plant community response to environmental change because less plastic species may become more abundant than more plastic species and because models that ignore plasticity can overestimate distributional shifts caused by global change (Thuiller et al. 2005).

Alpine plant communities and ecosystems are predicted to be very susceptible to changes caused by increasing nitrogen deposition (Bowman et al. 1993, 1995, 2006, Bowman 2000, Suding et al. 2008). Less phenotypically plastic alpine plant species may not adjust as well to the significant anthropogenic nitrogen deposition in some alpine areas (Baron et al. 2000), climatic warming, and the associated and documented colonization by lower-elevation plants (Walther et al. 2005, Jurasinski and Kreyling 2007, Lenoir et al. 2008, Parolo and Rossi 2008). Forbs, an important component of most alpine vegetation, are thought to vary allocation among vegetative parts less than graminoids do (Robinson 1994, Bowman et al. 1995). Most forbs also respond less positively than graminoids do to nutrient addition (Bowman et al. 1993). However, very limited data exist on plasticity of biomass allocation in alpine forbs.

We used an approximately 50-year-old disturbance and the surrounding undisturbed alpine community on Pikes Peak, Colorado, to study the variability of biomass allocation within 5 alpine forbs with contrasting growth forms. To our knowledge, no data on allocation exist for several of these species, while inclusion of species studied at other sites allows cross-site comparison. We predicted that differences between disturbed and undisturbed sites would lead to differences in size and biomass allocation in some species and that the flexibility in size and allocation would be related to growth form.

We studied sites at Windy Point, elevation $3650 \mathrm{~m}$, Pikes Peak, Colorado, 38 48 $55^{\prime \prime} \mathrm{N}$, $105^{\circ} 1^{\prime} 20^{\prime \prime} \mathrm{W}$. The southwest-facing slope of $15^{\circ}$ to $20^{\circ}$ is covered with a dry meadow turf community of Kobresia myosuroides and with lesser amounts of Geum rossii (botanical nomenclature follows the Natural Resources Conservation

${ }^{1}$ Department of Biology, Colorado College, Colorado Springs, CO 80903.

${ }_{2}^{2}$ Present address: Division of Pulmonary, Allergy, and Critical Care Medicine, University of Pittsburgh, Pittsburgh, PA 15213.

3Corresponding author. E-mail: jebersole@ coloradocollege.edu 
service PLANTS database [USDA-NRCS 2008]). This community is very similar to the dry meadow of the well-studied Niwot Ridge alpine site (Walker et al. 2001), a community documented as quite stable in species composition over more than half a century (Korb and Ranker 2001) but with some increase in nitrophiles in recent years (Bowman et al. 2006).

In the early 1900s, workers supervised by Frederic Clements of the Carnegie Institute used cut-and-fill to level 3 areas for construction of buildings. The buildings were removed in about 1940 (Maurice Schubert, personal communication), which left 3 disturbed areas $4-5 \mathrm{~m}$ wide $\times$ $13 \mathrm{~m}$ long. These disturbed areas, with organic matter in the soil, then recovered for the approximately 50 years prior to this study. Because the upslope portions of disturbed sites were topographic depressions, disturbed sites remained snow-covered approximately 2 weeks longer than adjacent undisturbed sites. The longer snow cover and lack of slope led to disturbed areas that were visibly and substantially moister than adjoining undisturbed areas for all but the end of the growing season.

Five common perennial forb species that occurred on both disturbed and undisturbed sites were chosen for analysis. Four species were collected by digging a cylinder approximately $20 \mathrm{~cm}$ in diameter and at least $10 \mathrm{~cm}$ deep around individual plants. Soil and belowground parts of other species were then removed. These 4 species were Minuartia obtusiloba (Caryophyllaceae), loosely caespitose with a large and variable number of stems; Allium geyeri (Liliaceae), single-stemmed with bulb; Hymenoxys grandiflora (Asteraceae), with a single determinate stem and one very large head; and Polygonum bistortoides (Polygonaceae), with a large rhizome and single determinate stem. The fifth species, Geum rossii (Rosaceae), a clonal species with large woody vertical rootstocks, was collected by taking a 10-cm-diameter core sample within a clone (rather than by excavating individuals), because ramets vary in age, size, water, and nutrient content within clones (Chambers 1991). In both sites, no graminoid species occurred in sufficient quantity to sample.

Each species on the Pikes Peak study sites was collected when it was judged to be at its maximum aboveground size for the season, from mid- to late July 1993. Interannual variability of peak season aboveground biomass is moderate on the very similar Niwot Ridge (Walker et al.
1994), and biomass measurements from a single season are judged to be a reasonable estimate for a particular site (Körner 1999). For each species, 8-10 individuals in both disturbed and undisturbed areas were randomly chosen. After storage for 1-2 days at $5^{\circ} \mathrm{C}$, each sample was separated into belowground parts, aboveground vegetative portions, and reproductive parts. Living roots were separated from soil with gentle manual manipulation, first when the samples were moist and then under running water. Flowers were cut from the stem directly beneath the bracts. For shoots, only green tissue of the current year was retained. Samples were dried at $40{ }^{\circ} \mathrm{C}$ until completely dehydrated, and then their mass was measured.

Because plants were divided at ground level, we included rhizomes (morphological shoots) as belowground mass and calculated ratios of belowground to aboveground mass (B:A), not root-to-shoot ratios. Data were analyzed with one-way analysis of variance with Minitab version 15 (Minitab, Inc., State College, PA). When necessary, we used square-root, logarithmic, or negative-reciprocal transformations to meet the parametric assumptions of normality of residuals and equality of variances.

Three of the 5 species had greater mean masses in disturbed sites than in undisturbed sites (Fig. 1). Allium geyeri was 2.6 times greater $(P=0.00)$, Minuartia obtusiloba 2.4 times $(P=$ $0.01)$, and Geum rossii 1.8 times $(P=0.05)$. Hymenoxys grandiflora and Polygonum bistortoides showed no differences in size between the 2 sites.

None of the 5 species, which ranged in B:A from $<1$ to about 6 , showed differences in the ratio of belowground to aboveground parts between disturbed and undisturbed sites (Fig. 1). Four of the 5 species showed no difference in biomass allocation to reproduction (Fig. 1); these included species with substantial variation in size. Only Geum rossii showed differences in allocation to reproduction, increasing 2.9 times, from $0.5 \%$ of total biomass in the undisturbed sites to $1.4 \%$ in the disturbed sites $(P=0.02)$.

Some differences in size plasticity among the 5 forbs associated with differences in growth strategies. The 2 species with variable numbers of modules per genet (M. obtusiloba and $G$. rossii) both showed flexibility in size. The 2 species that lacked significant differences in size between the 2 sites, $H$. grandiflora and $P$. bistortoides, have determinate growth forms, with a 

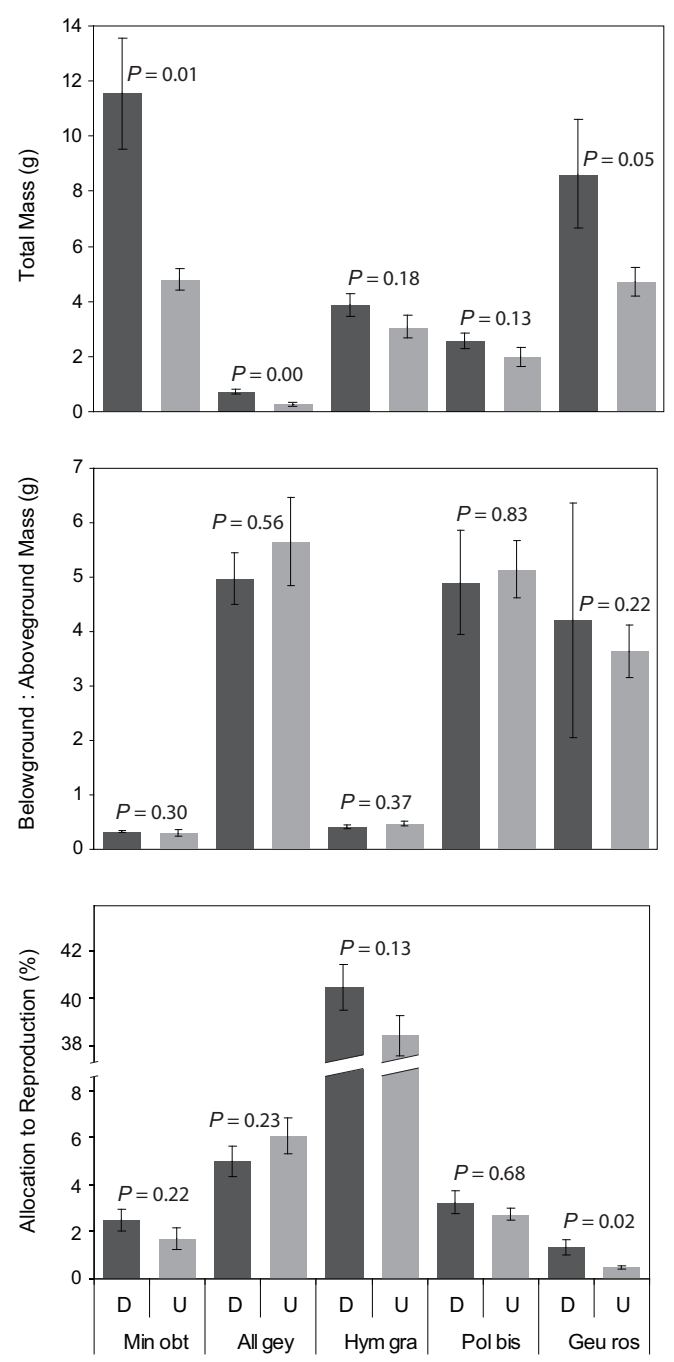

Fig. 1. Plant size, belowground : aboveground biomass allocation $(\mathrm{B}: \mathrm{A})$, and allocation to reproduction (mean $\pm \mathrm{SE}$ $n=8-10)$ in disturbed (D) and undisturbed (U) sites for 5 forbs. $P$ values are from oneway ANOVAs. Species abbreviations: Min obt $=$ Minuartia obtusiloba, All gey $=$ Allium geyeri, Hym gra = Hymenoxys grandiflora, Pol bis = Polygonum bistortoides, Geu ros $=$ Geum rossii. Calculations (Zar 1996) showed that minimal detectable differences in $\mathrm{B}: \mathrm{A}$ - given our sample sizes and variances, $\beta=0.1$, and $\alpha=$ 0.05-were 0.1 for $H$. grandiflora and M. obtusiloba, 2.0 for P. bistortoides, 2.1 for A. geyeri, and 3.5 for G. rossii.

single inflorescence terminating a single stem. Allium geyeri did not fit these patterns, since it has a determinate stem and nonclonal growth, but it was larger in the disturbed sites (Fig. 1).

Alpine forbs studied at other sites also vary in size plasticity and in response to variation in resources. Walker et al. (1995) showed that, through 8 years of climatic variation, G. rossii did not change in maximum leaf length or number of leaves and that $P$. bistortoides increased in size only in one year, after a winter with greater-than-usual snowpack. In response to fertilization, P. bistortoides stores excess nitrogen in the rhizome without increasing in size (Lipson et al. 1996).

The larger size in the disturbed site for 3 of the 5 species has several possible causes: less competition (about $20 \%$ cover compared to about $95 \%$ cover in the undisturbed areas), greater moisture in the disturbed sites (but see Bowman et al. 1993), or possibly higher nutrients (Bowman et al. 1993, 1995, Bowman and Bilbrough 2001) as organic matter mixed into the soils decomposed after building removal. It seems unlikely that the plants on the disturbances are different genetically from the undisturbed vegetation. The relatively small disturbed area of this study is located within a large, unbroken expanse of dry meadow, and, with the exception of $H$. grandiflora, our study species have gravitydispersed seeds. With the limited movement of these seeds, the genetic composition of the plants that colonized the disturbance is likely to be similar to or a subset of that in undisturbed areas. The inferred lack of genetic differentiation between disturbed and undisturbed sites implies that 3 of our study species have phenotypic plasticity in total mass.

Our 5 forb species varied substantially in B:A. Even though ratios of belowground to aboveground biomass at the community level in the alpine are generally high (e.g., Körner 1999, Bowman and Fisk 2001), 2 of the 5 forbs we measured had considerably more abovethan belowground biomass, while the remaining 3 showed a B:A of approximately $4: 1$ to $6: 1$ (Fig. 1).

None of the 5 species we studied showed plasticity in B:A between disturbed and undisturbed sites. This was true despite (1) differences in size for 3 species (Fig. 1), (2) a wide variety of growth strategies, (3) a wide range of B:A (Fig. 1), and (4) clear differences in moisture between disturbed and undisturbed sties. The lack of differences in B:A with differences in plant size is especially interesting since others have argued (for other species) that intraspecies variation in size may explain some B:A differences that have been attributed to differential responses to root competition and nutrient supply (Gedroc et al. 1996). In our data, the lack of 
change in B:A-even with a mean size difference of up to 2.6 times-implies a strongly fixed biomass allocation for these alpine plants.

Few data exist on B:A plasticity of alpine forbs. For alpine graminoid species, sedges have shown very little plasticity in this trait, while grasses are moderately to strongly plastic (Theodose 1995 cited in Bowman and Fisk 2001, unpublished data cited in Bowman et al. 1995, Theodose and Bowman 1997, Bowman and Bilbrough 2001). It appears that most alpine species, with the exception of grasses, have limited flexibility in B:A.

The 5 species also showed very low flexibility in proportion of biomass allocated to reproduction despite the differences in environment and, for some species, differences in plant size between disturbed and undisturbed sites. Four of the 5 species showed no differences between disturbed and undisturbed sites. Allocation by $G$. rossii to reproductive parts was significantly greater in disturbed sites $(P=0.02)$, but the increase was $<1 \%$ of total biomass.

Other studies of alpine forbs have shown a similar lack of plasticity in allocation to reproduction, especially in dry meadows. In Walker et al.'s (1995) study of effects of interannual variability in climate, Geum rossii and Polygonum bistortoides varied in flower number in some communities but not in the dry meadow. Saxifraga rhomboidea, in response to fertilization, also did not alter its reproductive allocation (Bechtold et al. 2003). Poa alpina showed little phenotypic variation in a reciprocal transplant experiment (Hautier et al. 2009). This same lack of plasticity was detected by Müller et al. (2000) in nutrient-poor, nonalpine sites. In passive warming experiments with open-top cham in Dryas integrifolia (High Arctic; Wookey et al. 1995) and Ranunculus nivalis (Low Arctic; Molau 1997). In contrast, Silene acaulis did not change seed mass but produced more seeds in the Middle Arctic though not in the alpine (Alatalo and Totland 1997). Proportion of biomass allocated to reproduction was not measured in these nondestructive experiments.

In some situations, lack of changes in reproductive allocation despite variation in resources may be due to developmental constraints (Bechtold et al. 2003), because alpine plants commonly preform buds (e.g., Meloche and Diggle 2001). In our study, plants experienced the different environment of the disturbed area for multiple decades, which suggests that reproductive allocation is quite fixed genetically and that changes in reproductive allocation are not simply a matter of inadequate time to respond in short-term fertilization experiments (compare Gedroc et al. 1996).

The low phenotypic plasticity in biomass allocation across a range of forb growth strategies suggests selection in these alpine forbs for quite conservative life history strategies. This conservative response was also recorded by Bowman et al. (1995) in some, but not all, forbs in a water and nutrient addition experiment. Selection for low plasticity may be due to the relatively high variability among growing seasons and persistently low levels of limiting soil resources (Bowman and Fisk 2001). In the future, this low phenotypic plasticity could limit the potential of these species to respond to rapid climate change and increased nitrogen deposition.

\section{ACKNOWLEDGMENTS}

We are grateful to Colorado Springs Utilities for access to the study site. A grant to the Colorado College Biology Department from the Howard Hughes Medical Institute supported field work of MMM.

\section{Literature Cited}

Alatalo, J.M., and $\varnothing$. Totland. 1997. Response to simulated climatic change in an alpine and subarctic pollenrisk strategist, Silene acaulis. Global Change Biology 3:74-79.

Baron, J.S., H.M. Rueth, A.M. Wolfe, K.R. Nydick, E.J. Allstott, J.T. Minear, and B. Moraska. 2000. Ecosystem responses to nitrogen deposition in the Colorado Front Range. Ecosystems 3:352-368.

Bechtold, H.A., T.A. Forbis, W.D. Bowman, and P.K. DigGLE. 2003. Lack of reproductive plasticity in alpine Saxifraga rhomboidea (Saxifragaceae). Nordic Journal of Botany 22:361-368.

Bowman, W.D. 2000. Biotic controls over ecosystem response to environmental change in alpine tundra of the Rocky Mountains. Ambio 29:396-400.

Bowman, W.D., AND C.J. Bilbrough. 2001. Influence of a pulsed nitrogen supply on growth and nitrogen uptake in alpine graminoids. Plant and Soil 233: 283-290.

Bowman, W.D., AND M.C. Fisk. 2001. Primary production. Pages 177-197 in W.D. Bowman and T.R. Seastedt, editors, Structure and function of an alpine ecosystem, Niwot Ridge, Colorado. Oxford University Press, New York, NY.

Bowman, W.D., J.R. Gartner, K. Holland, and M. WieDERMANN. 2006. Nitrogen critical loads for alpine vegetation and terrestrial ecosystem response: are we there yet? Ecological Applications 16:1183-1193.

Bowman, W.D., T.A. Theodose, AND M.C. FISK. 1995. Physiological and production responses of plant 
growth forms to increases in limiting resources in alpine tundra: implications for differential community response to environmental change. Oecologia 101: 217-227.

Bowman, W.D., T.A. Theodose, J.C. Schardt, and R. CONANT. 1993. Constraints of nutrient availability on primary production in two alpine tundra communities. Ecology 74:2085-2097.

Chambers, J.C. 1991. Patterns of growth and reproduction in a perennial tundra forb (Geum rossii): effects of clone area and neighborhood. Canadian Journal of Botany 69:1977-1983.

Gedroc, J.J., K.D.M. McConnaughay, and J.S. Coleman. 1996. Plasticity in root/shoot partitioning: optimal, ontogenetic or both? Functional Ecology 10:44-50.

Hautier, Y., C.F. Randin, J. Stocklin, and A. Guisan. 2009. Changes in reproductive investment with altitude in an alpine plant. Journal of Plant Ecology 2: 125-134.

JuRAsinski, G., AND J. KREYLing. 2007. Upward shift of alpine plants increases floristic similarity of mountain summits. Journal of Vegetation Science 18:711-718.

Korb, J.E., AND T.A. Ranker. 2001. Changes in stand composition and structure between 1981 and 1996 in four Front Range plant communities in Colorado. Plant Ecology 157:1-11

KörnER, C. 1999. Alpine plant life: functional plant ecology of high mountain ecosystems. Springer-Verlag, Berlin, Germany.

Lenoir, J., J.C. Gegout, P.A. Marquet, P. De Ruffray, and H. BRISsE. 2008. A significant upward shift in plan species optimum elevation during the 20th century. Science 320:1768-1771.

LiPson, D.A., W.D. Bowman, and R.K. Monson. 1996. Luxury uptake and storage of nitrogen in the rhizomatous alpine herb, Bistorta bistortoides. Ecology 77 1277-1285.

Meloche, C.G., AND P.K. Diggle. 2001. Preformation, architectural complexity, and developmental flexibility in Acomastylis rossii (Rosaceae). American Journal of Botany 88:980-991.

MOLAU, U. 1997. Responses to natural climatic variation and experimental warming in two tundra plant species with contrasting life forms: Cassiope tetragona and Ranunculus nivalis. Global Change Biology 3 (Supplement 1):97-107.

MÜLler, I., B. SCHMID, AND J. WEINER, 2000. The effect of nutrient availability on biomass allocation patterns in 27 species of herbaceous plants. Perspectives in Plant Ecology, Evolution and Systematics 3:115-127.
PAROLO, G., AND G. Rossi. 2008. Upward migration of vascular plants following a climate warming trend in the Alps. Basic and Applied Ecology 9:100-107.

Robinson, D. 1994. The responses of plants to non-uniform supplies of nutrients. New Phytologist 127:635-674.

Suding, K.N., I.W. Ashton, H. Bechtold, W.D. Bowman, M.L. Mobley, and R. Winkleman. 2008. Plant and microbe contribution to community resilience in a directionally changing environment. Ecological Monographs 78:313-329.

Theodose, T.A. 1995. Interspecific plant competition in alpine tundra. Doctoral dissertation, University of Colorado, Boulder, CO. 160 pp.

Theodose, T.A., AND W.D. Bowman. 1997. Nutrient availability, plant abundance, and species diversity in two alpine tundra communities. Ecology 78:1861-1872.

Thuiller, W., S. Lavorel, M.B. Araujo, M.T. Sykes, and I.C. Prentice. 2005. Climate change threats to plant diversity in Europe. Proceedings of the National Academy of Sciences 102:8245-8250.

USDA-NRCS. 2008. The PLANTS Database. National Plant Data Center, Baton Rouge, LA; [cited 26 July 2010]. Available from: http://plants.usda.gov

Walker, M.D., R.C. Ingersoll, AND P.J. WEbBer. 1995. Effects of interannual climate variation on phenology and growth of two alpine forbs. Ecology 76:1067-1083.

Walker, M.D. D.A. Walker, T.A. Theodose, and P.J. WEBBER. 2001. The vegetation: hierarchical speciesenvironment relationships. Pages 99-127 in W.D. Bowman, and T.R. Seastedt, editors, Structure and function of an alpine ecosystem, Niwot Ridge, Colorado. Oxford University Press, New York, NY.

Walker, M.D., P.J. Webber, E.H. Arnold, and D. EberTMAY. 1994. Effects of interannual climate variation on aboveground phytomass in alpine vegetation. Ecology 75:393-408.

Walther, G., S. Beillner, and C.A. Burga. 2005. Trends in the upward shift of alpine plants. Journal of Vegetation Science 16:541-548.

Wookey, P.A., C.H. Robinson, A.N. Parsons, J.M. Welker, C. Press, T.V. Callaghan, and J.A. LeE. 1995. Environmental constraints on the growth, photosynthesis and reproductive development of Dryas octopetala at a high Arctic polar semi-desert, Svalbard. Oecologia 102:478-489.

ZAR, J.H. 1996. Biostatistical analysis. 3rd edition. Prentice Hall, Upper Saddle River, NJ.

Received 24 August 2010 Accepted 13 June 2011 